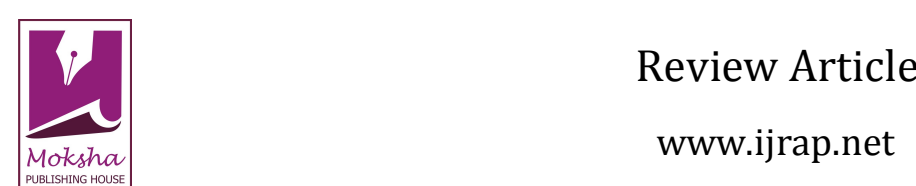

\title{
SHIBB-E-YAMANI (ALUM) A UNIQUE DRUG AND ITS UTILIZATION IN UNANI MEDICINE: A PHYSICOCHEMICAL AND PHARMACOLOGICAL REVIEW
}

Akhtar Ali ${ }^{1}$, Hamiduddin ${ }^{2 *}$, Mohammad Zaigham ${ }^{1}$

${ }^{1}$ Department of Ilmul Saidla (Unani Pharmacy), Z.H. Unani Medical Collage \& Hospital, Siwan

${ }^{2}$ Lecturer, Department of Ilmul Saidla (Unani Pharmacy), National Institute of Unani Medicine (NIUM) Kottigepalya,

Magadi main Road, Bengaluru, India

${ }^{3}$ PG Scholar, Department of Ilmul Saidla (Unani Pharmacy), National Institute of Unani Medicine (NIUM)

Kottigepalya, Magadi main Road, Bengaluru, India

Received on: 03/01/17 Revised on: 18/02/17 Accepted on: 22/02/17

\author{
*Corresponding author \\ E-mail: drhamid2003@rediffmail.com
}

DOI: $10.7897 / 2277-4343.08255$

\section{ABSTRACT}

Phitkari (Alum) is a very renowned and useful drug in Unani and Ayurvedic system of medicine. It is a drug of mineral origin, found in the form of crystals resembling to salt. It is called Zaj-e-Abyaz in Arabic and Shibb-e-Yamani in Persian, and Alum in English. It is a very ancient medicine; first time Alum was prepared in Bilade Mashriqiya (Asian countries). The earliest surviving discussions of Phitkari in the literature of antiquity are the works of the Greek physician Dioscorides. Arab physicians especially Razi discussed it in details. Razi included Alum among the types of vitriol, probably due to the similarities in their astringent qualities and mode of occurrence in his Book of Secrets (Kitab al-asrar). It is used as antiseptic, antipyretic, antispasmodic, hemostyptic. It is also used in many compound formulations in various dosage forms. In this paper, Alum is reviewed for its pharmacological and physicochemical properties due to its importance and beneficent medical indications.

Keywords: Shibb-e-Yamani, Alum, Phitkari, drug, Unani, medicine, physicochemical, pharmacological activity

\section{INTRODUCTION}

Phitkari (Alum) is a mineral origin drug, named due to its Qabiz (astringent) property and action. ${ }^{1}$ It is called Zaj-e-Abyaz in Arabic and Shibb-e-Yamani in Persian, and Alum in English. ${ }^{2}$ According to Unani medicine literature it is styptic (Kasela), and some are sour in taste, It is soluble in water, dissolve when heated. ${ }^{3}$ Phitkari is transparent, Burraq (type of salt) like friable. ${ }^{4}$ It is soluble ten times in normal water and three times in warm water. ${ }^{5}$ Its weight is less than salt. ${ }^{15}$ Alum is a general double sulphates containing aluminium. ${ }^{6}$

Historical aspect: For the first-time Alum was prepared in Bilade Mashriqiya (Asian countries), it is very ancient medicine. According to author of Umdatul Muhtaj, Hippocrates mentioned about Phitkari. ${ }^{3}$ The earliest surviving discussions of Phitkari in the literature of antiquity are the works of the Greek physician Dioscorides (first century AD) ${ }^{3}$ and the Roman naturalist Pliny the Elder (79 AD). Dioscorides mentioned Alum as mineral due to its type of origin. Greeks called it 'chalcanthon', in Latin it was called Atramentum sutorium (blackening agent for leather). ${ }^{7}$ Ancient Greeks and Romans used aluminium salts as dyeing mordents and as astringents for dressing wounds; Alum is still used as a styptic.

Nature and types: According to Ibn Hubal Baghdadi Zaj are four types (1) Zaj-e-Abyaz (white Alum): that is free from sands and stones, also known as Qalqadees (2) Zaj-e-Asfar (yellow Alum) also known as Qalqatar (3) Zaj-e-Akhzar (green Alum) also known as Qalqand (4) Zaj-e-Ahmar (Red Alum) also known as Soori and Soghmar. All types of Zaj are soluble in water except Zaj-e-Ahmar because it is very tough, hard and coagulated. Zaj-e-Abyaz and Akhzar are best quality of them;
Zaj-e-Asfar is Mutadil. The best quality of Zaj is that, which is easily breakable. ${ }^{8,9}$ According to Al-Maghribi it has five types, and best type is Sabz Qabrisi, i.e. Lateef QawiI. ${ }^{10}$ Najmul ghani mention in Khazain al-Advia that there are 17 to 18 types of alum $^{3}$ but only three special types are used in treatment. (1) Sahti (Mushaqqaq) (broken in pieces) (2) Istriqooli means Mustadir (round shape) (3) Awagira means Ratab (wet). The best type of these is Mushaqqaq it is bright, white, fresh, more sour and clean from all types of adulterated sands like Tarheeli (another Shora) that is found in Egypt. ${ }^{2}$ According to Majusi it is found of various types, but best quality is "Misri Zaj" that is round, compact and light golden in colour. ${ }^{11}$ In nearly all the market in India, Alum (potash alum) in a more or less contaminated state is sold under the name of Phitkari (Hindustani / Indian name). It may be rendered fit for medicinal uses by dissolving it in water, to obtain crystals, evaporating the solution. It forms the main constituent, conjoined with peroxide of iron, of Salajet or Alum earth of Nepal, which forms an important article of the inhabitant Materia Medica. It is probably a form of iron-alum for an account of this drug and its uses. Another aluminous earth, named Pah. It was distinct to be a variety of feather alum, in which the potassa is replaced by peroxide of iron. Another earth from the same locality called Meth or Met; contain 13.16 percent of alumina and 17.80 percent of peroxide of iron. ${ }^{12}$

\section{Types of Alum}

Potassium Alum: It is aluminum potassium sulfate also known as tawas or potash alum. This is the type of alum that is found in the grocery store for pickling and in baking powder. It is also used in leather tanning, in water purification as a flocculants, in 
after shave as an ingredient and as a treatment to fireproof textiles. Its chemical formula is $\mathrm{KAl}\left(\mathrm{SO}_{4}\right)_{2}$.

Soda alum: Soda alum has the formula $\mathrm{NaAl}\left(\mathrm{SO}_{4}\right)_{2} \cdot 12 \mathrm{H}_{2} \mathrm{O}$. It is used in baking powder and as an acidulent in food.

Ammonium Alum: Its formula is $\mathrm{NH}_{4} \mathrm{Al}\left(\mathrm{SO}_{4}\right)_{2} \cdot 12 \mathrm{H}_{2} \mathrm{O}$. It is used for many of the same purposes as potassium alum and soda alum. Ammonium alum finds applications in tanning, flame retardant, textiles, dyeing making textiles, in the manufacture of porcelain cements in water purification, vegetable glues, and in some deodorants.

Chrome Alum: It is also known chromium alum. It has the formula $\mathrm{KCr}(\mathrm{SO} 4) 2.12 \mathrm{H} 2 \mathrm{O}$. It is deep violet compound used in tanning and can be added to other alum to grow lavender or purple crystals.

Selenate Alums: It occurs when selenium takes the place of sulfur, so that instead of a sulfate you get a Selenate, $\left(\mathrm{SeO}_{4}{ }^{2-}\right)$. The selenium containing alums are more strong oxidizing agents, so as antiseptics they can be used, among other uses.

Aluminum Sulfate: Another name of this compound is papermaker's alum. However, it is not technically alum. ${ }^{13}$ As found in the market, it is frequently mixed with impurities; it can be rendered fit for the medical uses by dissolving it in boiling water, straining the solution and evaporating it to obtain crystals. Alum is a general name for a class of double Sulphates containing aluminium and such metals as potassium, ammonium, iron etc. ${ }^{6} \mathrm{~A}$ double Sulphate of Ammonia and alumina, $\mathrm{NH}_{4} \mathrm{O}, \quad \mathrm{SO}, \quad \mathrm{Al}_{2} \mathrm{O}_{8}, \quad 3 \mathrm{SO}_{8}+24 \mathrm{HO}$ or $\mathrm{NH}_{4} \mathrm{Al}$ $\left(\mathrm{SO}_{4}\right)_{2} .12 \mathrm{H}_{2} \mathrm{O}$, prepared by different processes from aluminous shale. It occurs in the form of colorless, transparent, crystalline masses, exhibiting the faces of the regular octahedron, and having an acid sweetish astringent taste. ${ }^{6}$

Alumen exsiccatum (dried Alum): Prepared by taking four ounces of Alum and heating in a suitable vessel or other porcelain dish till it liquefies, heat is then raise and continue till aqueous vapor ceases to be disengaged, and the salt has lost 47 percent of its weight. Then residue is reduced to powder, and preserve in wall stopped bottle. Its property is similar to Alum, and more powerful. It is mild escharotics, its dose is $5-15$ grains. $^{12}$

Controversies (Unani \& general): Zaj in Unani medicine is referred to vitriol in several texts which is a group of mineral substances having sulfates of divalent metals. Vitriol are recognized in modern science as hydrated sulfates of divalent metals (iron, copper, magnesium and zinc), form as secondary minerals inside the weathering zones of metallic sulfide deposits, ancient time referred as ipyritesi. The iron and copper varieties of vitriol were widely recognized and utilized in the past, and were commonly referred to respectively as green [melanterite (FeSO4. $7 \mathrm{H} 2 \mathrm{O})$ ] and blue vitriol [chalcanthite (CuSO4 .5H 2O)]. An early attempt Persian physician and alchemist Muhammad ibn Zakkariya ar-Razi (c. AD 854925/935) systemize the classification of mineral substances beyond the level of metals, stones, and earths. In his Book of Secrets (Kitab al-asrar), written around $900 \mathrm{AD}$, Razi classified all substances known to him, first dividing them into four main groups: mineral, vegetable, animal, and derivatives of these. The latter included substances that ar-Razi was unable to include into any of the three preceding groups, as for example Litharge (basic lead carbonate), Verdigris (basic copper acetate), and
Tutia (zinc oxide). "Among Ar-Razis table of mineral categories vitriol appears as a class of six substances."

Razi included Alum among the types of vitriol, probably due to the similarities in their astringent qualities and mode of occurrence "According to Razi Six Atraments (metallic sulfates and their impurities) are: 1. Black atrament (impure $\mathrm{FeSO}_{4}$ ), 2. Alum (a rather vague category including $\mathrm{KAl}\left(\mathrm{SO}_{4}\right)_{2}$ in varying degrees of purity as well as other metallic sulfates) 3 . Calcandis or white atrament (qalqant in Arab it is a weathering product of copper/iron ores or alum) 4. Calcande or green atrament (qalqadis in Arab is iron and / or copper sulfate) 5. Calcatar or yellow atrament (qalqatar in Arab is decomposition product of sulfide and sulfate rich copper or iron ores, burnt iron vitriol /iron sulfate and iron oxide) 6. Surianum or red atrament (suri in Arab it is same as calcatar). ${ }^{7}$ Unani philosophers explains Zaj and Shibb both are different thing. According to Al-Majoosi, Zaj is Hot and dry and Shibb-e-Yamani is cold and dry in temperament. ${ }^{11}$ Zaj has more sour property. But in some text, both are equal with some conditions. ${ }^{3}$ Razi mentioned Alum as a type of vitriol, probably due to its mode of occurrence and astringent qualities and as if Alum had different medicinal and industrial use in comparison with vitriol, but both were prepared by similar way and even can be find together. ${ }^{7}$

Habitat: About all type of Alum are found in Egyptian mines. It is also found like Geru (red ocher) in Milas, Maqdunia, Linara, Soroon, Linaroos, Fruia, Nanwa, Arminia etc and various sites, ${ }^{2}$ also found in Yeman, Rajasthan, Bihar and Punjab. ${ }^{5,12}$ It is procured from various parts of countries especially from Lahore and Khushab. ${ }^{4}$ It synthesize in factories in north area of Sindh River, Khateri and Singhada in Jaipur, Mumbai, Chennai and Punjab. ${ }^{14}$ Alum predominantly found with peroxide of iron in Silajit or in Alum earths of Nepal or prepared from the alum shale's for commerce in the Punjab, Bihar, Rajputana, and Cuttack and else-ware States. Mostly in the soil in many parts of India, and it is prepared for commerce in Sindh, Cuttack, Bihar, Punjab, and elsewhere ${ }^{6,12}$ Alums occur naturally in various minerals. Potassium alum is found in the minerals Kalinite, Alunite, and Leucite, which can be treated with Sulfuric acid to obtain crystals of the Alum. ${ }^{15}$

\section{Vernacular Name}

Arabic: Zaj-e-Abyaz, ${ }^{2,4,6}$ Zaj, shibbe ${ }^{6}$, yaman. ${ }^{14}$ Urdu: Phitkari. ${ }^{14}$ English: Alum, ${ }^{2,14}$ Sulphate of Alumina and Potash or of Aluminium and Ammonium, Aluminous sulphate. ${ }^{6}$ Latin: Aluminum Sulphate ${ }^{14}$ Persian: Shibb-e-Yamani, ${ }^{2,6}$ Zake safed 4,14 Zake bilore. ${ }^{6}$ Hindi: Phitikhar, ${ }^{6}$ Phitkar. ${ }^{2,14}$ Sanskrit: Phatikari, Surashtraja, Kamakshi, Tuvari ${ }^{6}$ Sithi, Angda, ${ }^{14}$ Venmali. ${ }^{16}$ Bengali: Phatkiri. ${ }^{6}$ Guajarati \& Duk: Phatkari. ${ }^{6,14}$ Tamil: Patikaram, Adikharum, Shinacrum. ${ }^{6}$ Telgu: Pattikaramu, Padikharam. ${ }^{6}$ Canra: Phatikara. ${ }^{6}$ Sindh: Shinaaran. $^{6}$ Malay: Tawas. ${ }^{6}$ Maratha: Trae phitki. ${ }^{6,14}$ Punjabi: Phitkari. ${ }^{14}$

Unani morphology (mahiyat): It is a famous drug of mineral origin, found in the form of crystals resembling to salt but lesser in weight. ${ }^{4}$ (Figure 1) Shibb-e-Yamani (SY.) is a mineral origin drug. It has no odor, styptic and some sour in taste, soluble in water, dissolve when heated. According to Unani physician best quality of Alum is that, which is brittle on rubbing between the fingers. ${ }^{3}$ It was named due to its qabiz (astringent) property and action and as its jouhar is ghaleez. The lateef variety comes from Yemen; other variety is mustadeer (round). Shibb-e-Ratab and Shibb-e-Safayeh are very ghaliz in characteristic. ${ }^{1}$ (also 
available in crystal form ${ }^{17}$ of white in colour and some are yellowish also. ${ }^{4}$

Taste: Bakhatta kasila tez maza qadre shore (styptic sour and briny), ${ }^{4,18}$ shireen wa kasiala (sweet and styptic). ${ }^{5,8,17}$

Mizaj (Temperament): Hot \& Dry $3^{\circ},{ }^{17,19,20} \operatorname{Hot} 1^{\circ} \&$ Dry $2^{\circ},{ }^{3}$ according to others $\operatorname{Hot} 2^{\circ} \&$ Dry $3^{\circ} 14,18$ according to Some Hot $4^{\circ} \&$ Dry $4^{\circ},{ }^{3}$ Hot \& dry, ${ }^{11}$ Hot \& dry $3^{\circ}$ (at first stage/ Martabe awwal), ${ }^{4}$ Hot \&dry $2^{\circ} .{ }^{21}$

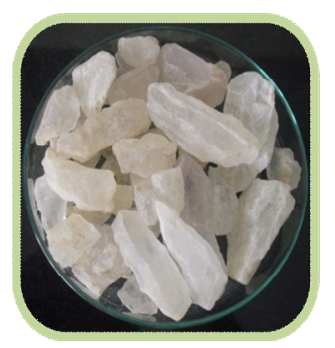

Figure 1: Phitkari (Alum)

Afal (pharmacological action) as per Unani literature: Akkal (corrosive), ${ }^{4,5,21}$ dafe' naubate tap (anti intermittent fever), ${ }^{17,21}$ dafe' tashannuj (antispasmodic / anticonvulsant), ${ }^{3}$ dafe' ta'ffun (antiseptic), ${ }^{5}$ dafe' tape larza (antipyretic), ${ }^{5}$ habis-i-dam (hemostyptic), ${ }^{3,5,17}$ jali (detergent), ${ }^{4,10,19}$ mane'-aashobe-chashm (anti-conjunctivitis) ${ }^{5}$ mudir (diuretic), ${ }^{17}$ mufattite-sange-gurdawa-masana (antilithiatic) ${ }_{4}^{4}$ mughalliz-i-mani (retentive of semen), ${ }^{3,17}$ muhallile auram (resolvent), ${ }^{3}$ muhallile riyah (resolvent of flatulence), ${ }^{4}$ muharriq (stimulant), ${ }^{8,9,11}$ muhayyij, ${ }^{17}$ muhazzil (Anti obesity), ${ }^{10}$ mujaffif (desiccant), ${ }^{10,17,19}$ mukhrije, janeen wa mashima (abortifacient) ${ }^{21}$ mulattif (demulcent), ${ }^{3,11}$ munbite sha'r (hair grower), ${ }^{10}$ mundamile qurooh (cicatrizant / healing agent), ${ }^{5}$ muqawi dandan wa lissa (strengthen the teeth and gums), ${ }^{4,19}$ muqi (emetic), ${ }^{17,21}$ musahhij (ulcerative), ${ }^{17}$ musakhin (calorific), ${ }^{2,17,19}$ muzayyiqe raham, ${ }^{41}$ nafe' lissa damia (useful in bleeding gums), ${ }^{19}$ nafe' zufra wa qaruhe lahme zaeda, ${ }^{19}$ qabiz (astringent). ${ }^{3,8,11}$

Nafa' khas (Important benefit): Amraze gurda wa masana and ain (diseases of kidney, urinary bladder and eyes), ${ }^{4}$ habisuddam (hemostyptic), mundamile qurooh (cicatrizant / healing agent). 5,21

Istemal (uses) as per Unani literature: Aag se jalna (post burn condition) $)^{2}$ aakila (rodent ulcer) ${ }^{20}$ aakilae dehan (gangrenous stomatitis) aakilae bini (scabies of the eye-lashes) ${ }^{20}$ aankh ki mail (cleaning eye) ${ }^{4,14}$ amraze farj zanana (vaginal diseases) 22 amraze lissa wa dandan (diseases of gums and tooth) ${ }^{21}$ aqr (sterility) ${ }^{14}$ arqun nasa (sciatica), ${ }^{20}$ ashob-i-chashm (acute conjunctivitis), ${ }^{14,17,18}$ aurame balghami, ${ }^{2,3}$ aurame jufn, (blepharitis), ${ }^{4}$ bad gosht from eye lids (malignant ulcer of eye lids), ${ }^{2}$ baghal ki badbu (bad ouder from axilla), ${ }^{2}$ baras wa bahaq (vitiligo and ptyriasis) ${ }^{3,10}$ bauluddam (heamaturia), ${ }^{6}$ bawaseer (hemorrhoid), ${ }^{10,14,21}$ bichhu ka zahar (scorpion poison), ${ }^{41}$ busoore labania, (acne vulgaris), ${ }^{2,3,14}$ busur (creeping ulcer), ${ }^{20}$ damma (asthma), ${ }^{14}$ daton ka hilna (shaky teeth) ${ }^{8}$ difda“ al-lisan (ranula) ${ }^{8,20} \mathrm{du}^{6} \mathrm{fe}$ Dandan wa lissa ${ }^{11,14}$ ganj (baldness) $)^{8,9}$ gastric and intestinal catarrh, ${ }^{6}$ hummae mewi (typhoid fever), ${ }^{14}$ ihtebase haiz (amenorrhea), ${ }^{17}$ indimale qurooh (cicatrization), ${ }^{9,17}$ ishal (purgation) ${ }^{14,21}$ ishale muzmin (chronic diarrhea) ${ }^{17}$ istisqae lahmi (anasarca) ${ }^{3}$ jala (vision problem), jiryan, sayalane mani (spermatorrhoea) ${ }^{14,22}$ jiryan al-dam, (heamorrhage), ${ }^{10,17,21}$ nafsud dam (hemoptysis) ${ }^{6,14}$ rua'f, (nakseer) (apistaxis), ${ }^{8,17,20}$ kasrate haiz (menorrhegia),6,10 kharish tar wa khushk (pruritis and scabies), ${ }^{4,17}$ kharishe mahbal (vaginal itching, ${ }^{17}$ khrujul maqad (rectal prolapse),17,21 khunaq (diphtheria),17,21 khushk kharish (dry scabies) ${ }^{2}$ khushkie sadr (dryness of the lungs) 20 khushunate ajfan (dryness of eye lids), ${ }^{16}$ mashara (erysipelas) ${ }^{20}$ nakhuna, (pterygium) ${ }^{14}$ nasoor (fistula), ${ }^{8,9,10}$ nasur (fistula) ${ }^{20}$ naubati bukhar (paroxysmal fever), ${ }^{17,21}$ nisyan (dementia), ${ }^{14}$ pasina (perspiration), ${ }^{14}$ qai (vomiting), ${ }^{22}$ qarhul uzun (auricular ulcers) ${ }^{, 20}$ qula'dehan (stomatitis), ${ }^{, 2,3,17}$ quroohe gurda wa masana wa ihleel (ulcers of kidney, urinary bladder and urethra), ${ }^{4,14}$ quroohe khabeesa (malignant ulcer), ${ }^{8}$ quroohe uzun (ulcer of ear), ${ }^{8}$ quruhe litha mutaffina (malignant gum swellings) sa' $\mathrm{fa}$ (favus) ${ }^{20}$ sange gurda wa masana (stone of kidney and urinary bladder), ${ }^{4,18}$ sanp ka zahar (snake poison), ${ }^{14}$ sar ki bhusi (dandruff) $^{2}$ sayalan al-rahim (leucorrhoea), ${ }^{, 6,17,18}$ shaheeqa (whooping cough), ${ }^{9,14,17}$ shaqeeqa (migraine), ${ }^{14}$ siql sama't (hearing impairment) ${ }^{3}$ sozak (gonorrhea) ${ }^{17}$ suda' (headache) $)^{3,14,18}$ ta'ffune lissa (infected gums), ${ }^{8}$ taakkule asnan (dental caries), ${ }^{20}$ tahabbuje atraf (peripheral edema), ${ }^{3}$ taqteerul boul (dribbling of urine), $)^{22}$ tar kharish (wet scabies), ${ }^{3,8,20}$ tarikiee chashm $^{2}$ tishnagi atash (thirst),22 wajul asnan (toothache), ${ }^{3,9,14}$ wajul uzun wa quroohul uzun (otolgia and ulcer of ear), ${ }^{9,14}$ warme halaq (laryngitis), 17,21 warme louzatain (tonsillitis), 17,21 warme mahbal (vaginitis), ${ }^{17,21}$ white spot in nail (koilonychia), ${ }^{2}$ yarqan (jaundice) ${ }^{14}$ zarirul asnan (shaky teeth) ${ }^{2,20}$

Pharmacological action and uses as per other literature: Antiseptic, 6,12 albuminuria, antispasmodic, aphonia, arrest excessive menstrual bleeding, in asthma, ${ }^{6}$ astringent, ${ }^{2,6,12}$ atonic diarrhea, ${ }^{12}$ atony of the Larynx bed sores, bleeding from Gums, Nose, Vagina or Rectum and other mucous surfaces, bleeding Piles, ${ }^{6}$ bronchoroea catarrhal affections of the stomach, catarrhal ophthalmia, ${ }^{12}$ caustic, chronic and purulent ophthalmia, chronic Conjunctivitis, ${ }^{6}$ colica pictonum, ${ }^{12}$ concussion of the Brain or Spinal Cord, Cough, Diabetes, Diphtheria, ${ }^{6}$ ecchymosis of the eye (as a collyrium), ${ }^{12}$ emetic in repeated dose, enteric fever, excessive salivation, ${ }^{6}$ exuberant granulations, ${ }^{12}$ Fissures of the tongue, fluxes profuse ropy mucous phlegm, fractures, Gonorrhea, ${ }^{6,12}$ Cholera, haemostatic, hemorrhage from Kidneys Lungs and other organs such as Stomach, Uterus and Kidneys, in hiccup, ${ }^{6}$ hospital gangrene infantile cholera, ${ }^{12}$ Injuries, Insect and Scorpion Bites, Irritant and purgative (in large dose) Chronic diarrheas, Diarrhea of phthisis, ${ }^{6} \quad$ leucorrhoea, ${ }^{6,12}$ Loose Teeth, Malaria, ${ }^{6}$ Menorrhagia, ${ }^{6,12}$ Narcotic poisoning ${ }^{6}$ Ophthalmia neonatorum, ophthalmia tarsi, $^{12}$ Otorrhoea, ${ }^{6}$ passive hemorrhages, ${ }^{12}$ Pharyngitis, ${ }^{6}$ Post Partum Hemorrhage, ${ }^{6}$ profuse discharge ulcerations, ${ }^{12}$ Prolapsus Ani, ${ }^{6}$ prolaps of Uterus and Rectum (as an injection), ${ }^{12}$ Vomiting, relaxed or ulcerated sore-throat, severe sprains, spongy or bleeding Gums, strangury, ${ }^{6}$ styptic, ${ }^{12}$ sweating feet, swollen Gums, bronchospasm, toothache, Ulcers of the Mouth and Tongue, Urethral discharge, Urethral stricture, ${ }^{6}$ Whooping cough. ${ }^{6,12}$

Ayurveda and other traditional medicine uses: Wound/ Ulcer, Leprosy, in poisoning, gonorrhea, Meningitis, disorder of phlegm and bile, vomiting, Cholera, Epistaxis, Stomatitis, Asthama, ear ache, absorbent, astringent, steptic, light irritant, quatrative, wormicidal ${ }^{6}$

Sozishe, Burning, Uvulitis, Irritation in tonsils, mouth ulcers, diphtheria, hoarseness of voice, chronic cough, chronic diarrhea, hemorrhage, dysentery, prolapsed of rectum, throat pain, Mouth Ulcers, Conjunctivitis, ${ }^{3}$ adjuvant in vaccines, skin whitener. ${ }^{15}$

Other than medicinal uses: Useful as coloring agent so it is called Randa $\cdot{ }^{14}$ It is constantly applied in saturated cloths ${ }^{6}$ after shave treatment for centuries, for Water Purification as 
flocculating agent, as a wonderful deodorant due to its antiseptic and anti bacterial properties, for body hair removal for women, for wrinkles. ${ }^{23}$ In paper making, as a mordant (binder) in dyeing, it fixes dye to cotton and other fabrics, rendering the dye insoluble, in pickling, in baking powder, in fire extinguishers. In toothpaste, an ingredient in some homemade and commercial modeling clay, flame retardant etc. ${ }^{15}$

Mazarrat (Toxicity as per Unani medicine): For lungs, sometimes destructs lungs cells by his Quwate tajfeef, $8,9,19$ Produce sil wa diq (Tuberculosis) ${ }^{10}$ for Intestine, ${ }^{3}$ for Stomach, ${ }^{3,4,19}$ karab wa khunaq (distressing pain and ludwig's angina)..$^{5}$ All kind of vitriol are caustic, produce dandruff white vitriol is most astringent while the yellow one is moderately so, ${ }^{2}$ irritation of the skin and mucous membranes. Breathing alum can cause lung damage; ingesting alum will make you vomit. ${ }^{13}$

Reported toxicity: Peazella et al. reports the case of a patient with renal failure following a bone marrow transplantation that developed an acute encephalopathy from apparent aluminum intoxication following intravesical alum. ${ }^{24}$ Kanwar et al. reported mental status changes, speech disturbance, coarse tremor, and abnormal EEG findings following intra-vesical 1\% alum irrigation and administration of aluminum-containing antacids in a teenage girl with acute lymphoblastic leukemia. Slightly elevated serum albumin levels and bone marrow biopsy demonstrated aluminum deposition ${ }^{25}$ Perl et. al. studied three cases of senile dementia (Alzheimer type) and three nondemented elderly controls, Foci of aluminum were detected within the nuclear region of a high percentage of neurons containing neurofibrillary tangles from the cases of senile dementia as well as the elderly controls. The adjacent normalappearing neurons from both groups of patients were virtually free of detectable aluminum. These findings suggest that the association of aluminum to Alzheimer's disease extends to the neuronal level. ${ }^{26}$ Aluminium can be deposited in bone and the central nervous system, particularly in patients with reduced renal function. Because aluminium competes with calcium for absorption, increased amounts of dietary aluminium may contribute to the reduced skeletal mineralization (osteopenia) observed in preterm infants and infants with growth retardation. In very high doses, aluminium is associated with altered function of the blood-brain barrier. ${ }^{27} \mathrm{~A}$ small percentage of people allergic to aluminium experience contact dermatitis, digestive disorders, vomiting or other symptoms upon contact or ingestion of products containing aluminium (antiperspirants and antacids). In Person without allergies, aluminium is not as toxic as heavy metals, but there is evidence of some toxicity if it is consumed in amounts greater than $40 \mathrm{mg} /$ day per $\mathrm{kg}$ of body mass. ${ }^{28}$ Long Evans rats were treated for 90 days with watersoluble, insoluble or chelated aluminium compounds. Soluble and chelated aluminium compounds seriously worsened the learning ability, and the aluminium content of the brain was elevated. Acetylcholinesterase activity increased and cholineacetyltransferase activity decreased, resulting in a diminished cholinergic activity, which is a characteristic of Alzheimer's disease. ${ }^{29}$ Use of aluminium cookware, has not been shown to lead to aluminium toxicity in general, excessive consumption of antacids containing aluminium compounds and excessive use of aluminium-containing antiperspirants provide more significant exposure levels. Studies have shown that consumption of acidic foods or liquids with aluminium significantly increases aluminium absorption. ${ }^{30}$

Musleh (Corrective) as per Unani \& other literature: Roghane zard (ghee) and milk for lungs and intestine, ${ }^{4,18,19}$ Use of Roghane sard (Cold oil), Tar ashya (wet things), ${ }^{4,19}$ Shakar (sugar) wa Lua'baat (mucilage) for cough, ${ }^{3,5}$ women's milk. ${ }^{10}$ According to Vedas: Sheera of coriander leaves (Coriandrum sativum Linn.). ${ }^{6}$

Badal (Substitute): Noushadar (Ammonii chloridum), ${ }^{3,5,18}$ namke siyah (sodium chloride), ${ }^{3,10,18}$ ashkhar / khar / sajji, ${ }^{10}$ Phitkari Surkh (red alum), ${ }^{4,5,21}$ kafe darya (Cuttlefish bone). ${ }^{4,5}$

Miqdare khurak (dose): Sawa char jau, ${ }^{3} 2$ masha $(2$ gm $),{ }^{3} 1$ masha (1 gm), ${ }^{18}$ according to vedas: 5-10 ratti $(0.625-1.250 \mathrm{gm})$, upto 7 masha $(7 \mathrm{gm})$ if necessary, ${ }^{3} 2-4 \mathrm{ratti}(250-500 \mathrm{mg}),{ }^{17,21}$ $15 \mathrm{mg}$ (Shagufta), ${ }^{5} 1-5 \mathrm{ratti}(125-625 \mathrm{mg}$ ) (2 gm in some special case). ${ }^{14}$ from ten to twenty grains, it is best given conjoined with aromatics. For external or local application, the strength may range from four to ten grains to the ounce of fluid. ${ }^{12}$ miqdare muqi 3 masha $(3 \mathrm{gm}){ }^{21}$

Murakkabat (Important Unani formulations): Dawae sozak, habbe siyah, habbe sozak, jauhare kalan, ${ }^{31}$ jauhare naushadar, ${ }^{32}$ kuashate para, ${ }^{33}$ kuhl gule kunjad, kushate hadtal, ${ }^{31}$ kushate murakkab, kushtae gaudanti, ${ }^{32}$ kushtae sammulfar, kushtae sange basari, kushtae sange jarahat, kushtae seesa, kushtae shangarf, ${ }^{32}$ majune kundur, manjan musakkin, safoofe indar julab, safoofe Phitkari, safoofe surkh, shiyafe ahmar, shiyafe zufra degar, sunoon zard, sunoone kalan, sunoone khas, sunoone supari, surma muqawwie basar, susoone chob chini, tilae surkh, zaroore bhodal kushat. ${ }^{31}$

\section{Reported Pharmacological Activity}

Anti-Hemorrhagic: Patients of malignant hemopathies who developed cyclophosphamide-induced hemorrhagic cystitis were treated by continuous irrigation of the bladder with potassium alum. Hematuria ceased with $75 \%$ success rate in the treatment. $^{34}$ In a trial of 45 patients with tonsillectomy, Aluminium potassium sulphate $(>99 \%$ pure $)$ used as haemostatic agent and gauze pack on the other side in the tonsillar fossae reduced the operation time significantly $(28.6 \%)$, functioning blood loss by $19.7 \%$ and the number of ties used by $33.3 \%$ in comparison with control. ${ }^{35}$ The efficacy of alum in intravesical irrigation was analyzed after application to 9 patients with continuous and severe Urinary bladder haemorrhage. The bleeding Causes were radiation cystitis in 4 patients, vesicle invasion by cervical cancer in 3, bladder cancer in 1 and cyclophosphamide-induced cystitis in 1 . Although alum treatment was initially efficient for control of considerable bladder haemorrhage in all patients, eventually it failed to check the bleeding in 2 patients ( $78 \%$ success rate) ${ }^{36}$ Continuous vesicle irrigation was performed with 1 per cent alum solution without anaesthesia in 9 patients in whom massive bladder haemorrhage persisted despite evacuation of clots and normal saline irrigation for at least 24 hours. Hematuria ceased promptly in all patients, although the effect was transient in 3. There was no side effect observed. No alteration showed in the histological characteristics in biopsy of the tumour subsequent to alum irrigation. Biopsy of the normal-appearing bladder mucosa also showed no evidence of epithelial damage. ${ }^{37}$

Antimicrobial activity: Antibacterial activity was reported of potash alum when it is added to water, against various epidemic causing enteric pathogens like Vibrio cholerae $01, \mathrm{~V}$. cholerae 0139 and Shigella dysenteriae 1, by lowering the $\mathrm{pH}$ of water (from 6.0 to 4.0). Potash alum was found to check the growth 10 (5) viable counts per $\mathrm{ml}$ of most of the organisms examined, particularly V. cholera 01 and V. cholerae 0139 in a dose dependent fashion. Reduction of colony forming units in presence of $0.25 \mathrm{~g} / \mathrm{dl}$ of alum after $5 \mathrm{~h}$ was observed and no 
growth was noticed after $24 \mathrm{~h} \cdot{ }^{38} \mathrm{~A}$ in vitro study on efficacy and safety of Potassium Aluminum Tetra-oxo-sulphate (Alum) in the treatment of tuberculosis using the proportion method revealed that at $0.003 \mathrm{~g} / \mathrm{ml}$ of highest concentration, Mycobacterium tuberculosis showed resistant to the alum extract where as Streptomycin (standard drug) inhibited the growth of $\mathrm{M}$. tuberculosis at the similar concentration. Various organ on histological analysis displayed normal morphology with no sign of inflammation. No significant weight difference was observed and no any mortality recorded during the experimental process. The histological studies revealed that at concentration used alum was relatively safe for mammalian use, but it was insignificant against M. tuberculosis. ${ }^{39}$

Antimicrobial activity was evaluated of crude extract prepared from alum and clove against S. aureus, S. epidermidis, E. coli, Klebsiella pneumonia. Over different concentration (10, 20, 30, 40 and 50$) \mathrm{w} / \mathrm{v} \%$, by in vitro bioassay using agar well diffusion method and minimum inhibitory concentration and the diameter of inhibition zone were determined. It exhibited antibacterial and growth inhibition activity of gram positive and negative bacteria isolated from different sites of infection and the effect was also compared with standard cefotaxime. ${ }^{40}$

Antimicrobial activity of Alum, propolis and plant aqueous extracts at $50 \%$ concentration by well-diffusion method was characterized by inhibition zones, the maximum inhibition zone diameters $35 \mathrm{~mm}, 40 \mathrm{~mm}$ were found in Salvadora persica and alum respectively, for propolis the inhibition zone was $30 \mathrm{~mm}{ }^{41}$

Spermicidal activity: Spermicidal effect Viability and motility of alum vary with different concentration of potash alum. In case of $15 \%$ concentration the death time was $51.9 \%$ sec in case of $10 \%$ it was $87.2 \mathrm{sec}$ and in case of $5 \%$ it was $122.1 \mathrm{sec}^{42}$

Anticariogenic effect: The anticariogenic effect of alum containing mouth rinses by measuring the salivary $\mathrm{S}$ mutans levels of children showed significant reductions in $\mathrm{S}$ mutans levels in children. ${ }^{43}$ In another study children using saturated saline rinse and alum rinse showed significant reductions in salivary S. mutans counts after 10 and 21 days over the placebo rinse group, the alum group showed significant difference over the saturated saline rinse group. ${ }^{44}$

Anti-obesity effect: In Wistar rats fed on high fat diet, oral intake of potash alum exhibited significant reduction in body weight, food intake, serum triglycerides, total cholesterol and high density lipoproteins, whereas increased the dry weight of feces, total lipids in feces compared to control. ${ }^{45}$

Ulcer healing activity: Randomized double-blind placebo controlled study was done on 52 patients with recurrent aphthous ulceration divided in 5 groups $(1,3,5,7 \%)$ of alum suspension, and placebo (applied topically four times daily for five days). In clinical evaluation of subjective treatment response and duration of lesion healing significant reduction was noted in 3, 5, $7 \%$ of alum concentrations in respect of the time required for complete healing of the ulcer when compared with placebo group. ${ }^{46}$

Larvicidal effect: Larvicidal potential of potash alum was investigated on A. stephensi under laboratory conditions. Potash alum was also found to be effective against all instar larvae. The LC50 and LC90 value of alum among various larvae on 24 hour' exposure ranged between 2.1 to $48.74 \mathrm{ppm}$ and 15.78 to $93.11 \mathrm{ppm}$, respectively. ${ }^{47}$

\section{DISCUSSION}

Shibb-e-Yamani is a mineral origin drug, named due to its Qabiz (astringent) property and action. It is a very ancient drug / medicine. In nearly all the market in India Alum (potash alum) in more or less contaminated state is sold under the name of Phitkari (Indian name). Arabs literatures indicate that the Arab Physicians are well known about Shibb-e-Yamani. Razi included Alum among the types of vitriol, probably due to the similarities in their astringent qualities and mode of occurrence. In Unani System of Medicine the Shibb-e-Yamani is very useful and valuable drug. It is used in various types of diseases as a dafe' ta'ffun (antiseptic), dafe' tape larza (antipyretic), habis-i-dam (hemostyptic), muhallile auram (resolvent) etc.

\section{CONCLUSION}

It can be concluded that Shibb-e-Yamani (Alum) can be promoted for its usefulness and utility in Unani system of medicine owing to its reported pharmacological activity. Further validation of other activity mentioned in Unani medicine can also be performed in view of findings of this review.

\section{REFERENCES}

1. Razi Z. Kitab Al-Hawi (Urdu Translation by CCRUM). Vol. XXI. Part. I. $1^{\text {st }}$ ed. New Delhi: CCRUM; 2007.p.72.

2. Baitar I. Al-Jame Limufradat Al-Advia wa Al-Aghzia (Urdu Translation by CCRUM). Vol-III. New Delhi: CCRUM; 1999. p. 118, 119.

3. Najmulghani. Khazain Al-Advia. New Delhi: Idara Kitab Al-Shifa; YNM. p. 482.

4. Hakim HMA. Bustan Al-Mufradat Jadid. New Delhi: Idara Kitab Al-Shifa; 2002. p. 176, 177.

5. Rafiquddin M. Kanzul Advia Mufrada. $1^{\text {st }}$ ed. Aligarh: University Publication Unit, AMU, Aligarh; 1985.p. 54.

6. NadKarni KM. Indian Materia Medica. Vol II. Mumbai: Popular Prakashan; 1982.p. 3.

7. Vladimõr Karpenkoa And John A. Norris, Vitriol In The History Of Chemistry, Chem. Listy 2002;96:997-1005.

8. Bhaghdadi AIH. Kitab Al-Mukhtarat. Fi Al-Tibb (Urdu

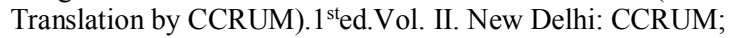
2005. p. 127-129.

9. Al-Attar Z. Ikhtiyarat-e-Badiei. Lucknow: Matba Nawal Kishore; 1889. p.108.

10. Al-Maghribi ASBI. Kitab Al-Fatah Fi Al-Tadawa Min Jamie Sunufil Amraz Wa Al-Shakawa (Urdu Translation by Hakim Abdul Bari). $1^{\text {st }}$ ed. New Delhi: CCRUM; 2007.p. 106.

11. Majusi ABA. Kamil Al-Sana'h (Urdu Translation by CCRUM). $1^{\text {st }}$ ed. II(Part II) New Delhi: CCRUM; 2010.p. 286.

12. Waring EJ. Pharmacopoeia of India. Indian Reprint ed. Delhi: Asiatic Publishing House; 2010.p. 343.

13. What Is Alum? Alum Facts, Types, Uses, and More. http://chemistry.about.com/od/

foodchemistryfaqs/f/Is-Alum-Safe.htm. accessed on $3 / 21 / 2016$.

14. Multani HC. Hindustan Aur Pakistan Ki Jadi Butiyan. Lahor: Maktaba Daniyal; YNM. p. 836-39.

15. Alum, Chemical compound http://www.britannica.com/ science/alum, accessed on 21-03-16.

16. Ayub M. Tarjumah Aqsarai sharah mojaz (urdu translation). Vol I. Lucknow: Matba Munshi Naval Kishore; YNM: 694.

17. Kabiruddin HM. Ilmul Advia Nafisi. New Delhi: Ijaz Publishing House; 2007.p. 259. 
18. Nabi G. Makhzane Mufradat Wa Murakkabat. $2^{\text {nd }}$ ed. New Delhi: CCRUM; 2007.p. 89.

19. Halim A. Mufradate Azizi. New Delhi: CCRUM; 2009.p. 21.

20. Sina I. Al-Qanun Fil-Tib (English Translation by Dept. of Islamic Studies Jamia Hamdard). $1^{\text {st }}$ ed. Vol-II. New Delhi: Jamia Hamdard; 1998.p. 232-33.

21. Kabeeruddin HM. Makhzan Al-Mufradat. New Delhi: Faisal Brother; 2000.p. 141, 142.

22. Khan S. Taleefe Shareefi. Delhi: Matba Darul salam; YNM.p. 61

23. Amazing Uses \& Benefits of Alum/ Fitkari For Health, Hair \& Skin. http://www.wildturmeric.net/2014/06/10-amazinguses-benefits-of-alum.html. accessed on 21.03.16.

24. Perazella, Mark, and Eric Brown. "Acute aluminum toxicity and alum bladder irrigation in patients with renal failure." American journal of kidney diseases 1993;21.1:44-46.

25. Kanwar, Vikramjit S., et al. "Aluminum toxicity following intravesical alum irrigation for hemorrhagic cystitis." Medical and pediatric oncology 1996;27.1:64-67.

26. Perl, Daniel P., and Arnold R. Brody. "Alzheimer's disease: $\mathrm{X}$-ray spectrometric evidence of aluminum accumulation in neurofibrillary tangle-bearing neurons." Science 1980;208.4441:297-299.

27. Banks WA, Kastin AJ. Aluminum-induced neurotoxicity: alterations in membrane function at the blood-brain barrier. Neuroscience \& Biobehavioral Reviews. 1989;13(1):47-53.

28. Dolara P. Occurrence, exposure, effects, recommended intake and possible dietary use of selected trace compounds (aluminium, bismuth, cobalt, gold, lithium, nickel, silver). International journal of food sciences and nutrition. 2014;65(8):911-24.

29. Bilkei-Gorzo A. Neurotoxic effect of enteral aluminium. Food and chemical toxicology 1993;31(5):357-61.

30. Slanina P, Frech W, Ekström LG, Lööf L, Slorach S, Cedergren A. Dietary citric acid enhances absorption of aluminum in antacids. Clinical chemistry 1986;32(3):53941.

31. Kabiruddin HM. Bayaz-e-Kabeer Vol-II. New Delhi: Idara Kitab Al-Shifa; 2010.p. 60, 35, 23, 112, 212, 139, 179, 56, $158,72,78,160,79,114,116,13$.

32. Kabiruddin HM. Kitab Al-Taklees. New Delhi: CCRUM; YNM. p.19, 20, 24, 52, 56-67, 70-204.

33. Firozuddin M. Madanul Akseer. New Delhi: CCRUM; 2007. p. $22,26,40,43,47-171$.

34. Gattegno B., et al. "Treatment of hemorrhagic cystitis caused by cyclophosphamide using intravesical instillation of potassium alum. Apropos of 5 cases." Annales d'urologie 1989;24(3). p. 190-192.

35. Al-Abbasi AM. The Benefit of Alum in Tonsillectomy. Gomal Journal of Medical Sciences 2009;7(2):124-127.
36. Takashi M, Kondo A, Kato K, Murase T, Miyake K. Evaluation of intravesical alum irrigation for massive bladder hemorrhage. Urol Int 1988; 43(5): 286-8.

37. Goel AK, Rao MS, Bhagwat AG, Vaidyanathan S, Goswami AK, Sen TK. Intravesical irrigation with alum for the control of massive bladder hemorrhage. J Urol 1985;133(6):956-7.

38. Dutta S, De SP, Bhattacharya SK. In vitro antimicrobial activity of potash alum. The Indian journal of medical research 1996;104:157-9.

39. Osuala FI, Ibidapo-obe MT, Okoh HI, Aina OO, Igbasi UT, Nshiogu ME et al. Evaluation of the Efficacy and safety of Potassium Aluminium Tetraoxosulphate (Vi) (ALUM) in the Treatment of Tuberculosis. European Journal of Biological Science 2009;1(1):10-14.

40. Bnyan IA, Alta'ee AH, Kadhum NH. Antibacterial Activity of Aluminum Potassium Sulfate and Syzygium Aromaticum Extract Against Pathogenic Microorganisms. Journal of Natural Sciences Research 2014;4(15):11-14.

41. Mohammad HH. In vitro Antibacterial Activity of Propolis, Alum, Miswak, Green and Black Tea, Cloves Extracts Against Porphyromonas Gingivalis Isolated from Periodontitis in Hilla City, Iraq. AJPCT 2013;1(2):140-148.

42. Singh HP, Singh CK, Singh RR. Effect of Potash Alum (Alluminium Potassium Sulphate) on Human Semen and Sperm. Indian J Pharmacol 1998;42(2):311-314.

43. Mourughan K, Suryakanth MP. Evaluation of an alumcontaining mouth rinse for inhibition of salivary streptococcus mutans levels in children-A controlled clinical trial. J Indian Soc Ped Dent 2004;22(3):100-105.

44. Rupesh S, Winnier JJ, Nayak UA, Rao AP, Reddy NV. Comparative evaluation of the effects of an alum-containing mouth rinse and a saturated saline rinse on the salivary levels of Streptococcus mutans. J Indian Soc Pedod Prev Dent 2010;28(3):138-144.

45. Ahmed Z, Afzal M, Kazmi I, Gupta G, Ahmad I, Anwar F. Anti-obesity potential of Potash Alum: Pharmacological and Biochemical Approach. Int J Pharm Pharm Sci 2012;4(4):90-93.

46. Altaei TS, Al-Jubouri RH. Evaluation of the efficacy of alum suspension in treatment of recurrent ulcerative ulceration. J College Dentistry 2005;17(2):45-48.

47. Preet S, Seema KC. Mosquito larvicidal potential of potash alum against malaria vector Anopheles stephensi (Liston). J Parasit Dis 2010;34(2):75-78.

\section{Cite this article as:}

Akhtar Ali et al. Shibb-e-yamani (alum) a unique drug and its utilization in Unani medicine: A physicochemical and pharmacological review. Int. J. Res. Ayurveda Pharm. 2017;8(2):17-22 http://dx.doi.org/10.7897/2277-4343.08255

Disclaimer: IJRAP is solely owned by Moksha Publishing House - A non-profit publishing house, dedicated to publish quality research, while every effort has been taken to verify the accuracy of the content published in our Journal. IJRAP cannot accept any responsibility or liability for the site content and articles published. The views expressed in articles by our contributing authors are not necessarily those of IJRAP editor or editorial board members. 